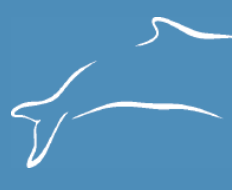

\title{
Rae Natalie Prosser de Goodall 1935-2015
}

Article Info

\begin{tabular}{|c|c|}
\hline Manuscript type & In Memoriam \\
\hline \multicolumn{2}{|l|}{ Article history } \\
\hline Received & 30 July 2015 \\
\hline Received in revised form & 31 July 2015 \\
\hline Accepted & 31 July 2015 \\
\hline Available online & 17 August 2015 \\
\hline \multicolumn{2}{|c|}{ Responsible Editor: Miriam Marmontel } \\
\hline \multicolumn{2}{|c|}{$\begin{array}{l}\text { Citation: Schiavini, A. (2015) Rae Natalie Prosser de Goodall } \\
\text { 1935-2015. Latin American Journal of Aquatic Mammals 10(1): } \\
\text { 68-69. http://dx.doi.org/10.5597/lajam00198 }\end{array}$} \\
\hline
\end{tabular}

While it is true that each person is unique, Natalie Goodall was part of that group of truly unusual people. She accomplished so much throughout her life and left a footprint on so many things that it is hard to summarize. Any account that claims to summarize her achievements is bound to be incomplete. It is an even greater challenge to write about someone who played such a key role in the scientific description of Tierra del Fuego - especially when that someone was a friend.

She was born on 13 April 1a935 on a ranch near Lexington, Ohio, in the north central United States. She earned a B.Sc. degree from Kent State University, Kent, Ohio. Her life took her to Venezuela to work as an elementary school teacher. Attracted by the reading of Lucas Bridges' book 'The Uttermost Part of the Earth', Natalie and a friend traveled around South America. In December 1962, they arrived at Harberton Ranch, Tierra del Fuego, where Natalie would meet her future husband, Thomas D. Goodall, the grandnephew of Lucas Bridges. They were married in 1963, and she started living at Harberton Ranch.

To manage life on a ranch on the shores of the Beagle Channel in the 1960s while raising two girls was no easy task. However, Natalie found time to study the history and nature of the land around her. She started a herbarium, which became pivotal to understanding the flora of Tierra del Fuego and the most important collection of specimens since Joseph Banks collected in the region in 1769 while on his trip with Captain Cook around the world. Without her contribution, the 'Flora de Tierra del Fuego', we would not have today the reference that is basic foundation for understanding the botany in this corner of the Earth.

\section{Adrián Schiavini i ${ }^{\dagger, *}$}

†Consejo Nacional de Investigaciones Científicas y Técnicas (CONICET), Centro Austral de Investigaciones Científicas (CADIC), Bernardo Houssay 200 (V9410BFD) Ushuaia, Tierra del Fuego, Argentina Corresponding author, email: aschiavini@gmail.com

Her expeditions in search of plants led her to roam throughout the Fuegian Archipelago. Among these landscapes, she used to walk the beaches, and started bumping into the things anyone can find at the beach dead animals included. Her curiosity led her to collect, in an almost casual way, dolphin skulls. She started researching further, and found out that what she was finding was relatively little known to science. She then started contacting other biologists dedicated to cetaceans. And all of this at a time when email was not available; when a letter from Ushuaia to anywhere in the world might take weeks to arrive in other parts of the world.

A new period in her life thus started. She liked to call herself a 'beachcomber'. And indeed she was: there was no such thing as a quick walk on the beach with Natalie. Nothing escaped her collector's eye. All of her early funding was from the Committee for Research, National Geographic Society, Washington, D.C., USA. As she received more funding, she started beachcombing more often, but now she focused on finding small cetaceans. She roamed the beaches with her all-terrain cycles, always aware that the large tides of the zone did not trap her against the cliffs. Lacking a GPS at first, and either using the speedometer of her cycles or placing sticks at regular distances in the large San Sebástian Bay, she recorded the exact location of each stranding.

When she started collecting cetaceans, only a few species were known from southern South America and there were few specimens. Through her work, the number of known species grew rapidly and the cetacean fauna of southern South America was discovered to be more diverse than previously thought. 


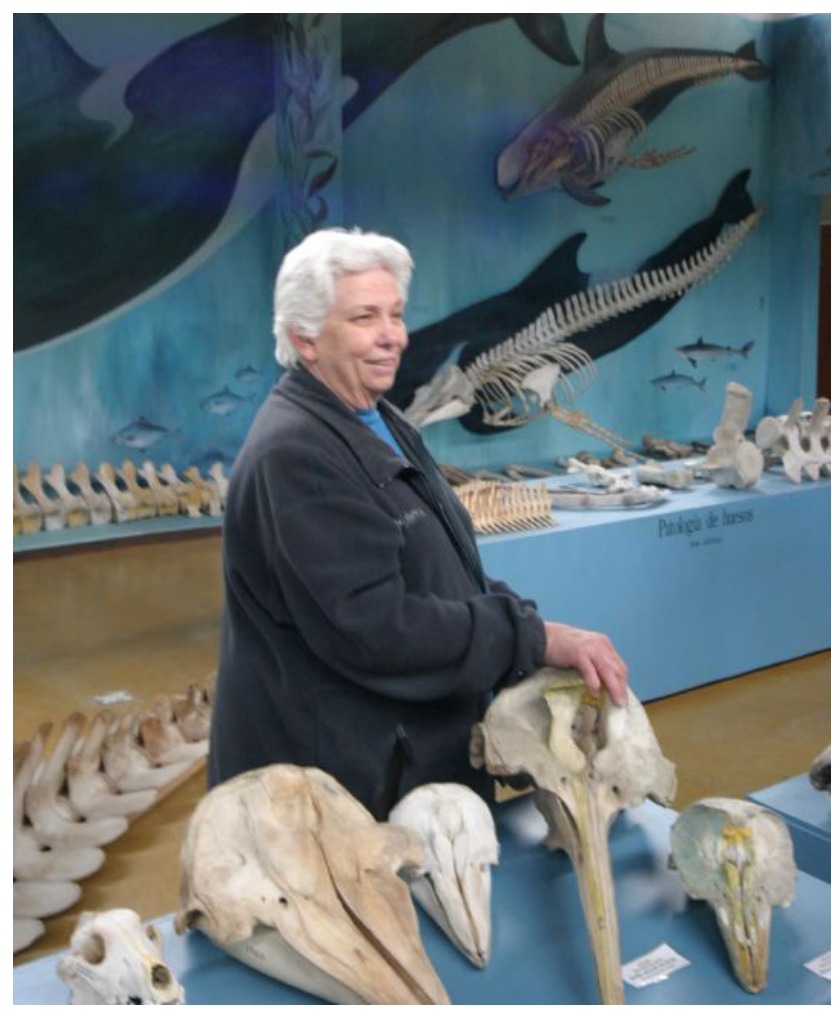

Collecting dead cetaceans in Tierra del Fuego is not now, and was not then, a simple task. The temperature in the area rapidly mummifies dead animals. For this reason, Natalie had to retrofit her house in Ushuaia to turn part of it into a laboratory: outside, containers to boil the recovered remains; inside, counters to catalog everything and cabinets to organize and keep specimens. A single record book allowed her to catalog all specimens, from number one (a pilot whale) through number 2884 (incidentally another pilot whale).

She also kept records of observations of live animals, mainly cetaceans, using forms that she distributed to anyone who was willing to provide information. Fishermen, sailors, and boat captains all carried her forms and contributed observations on live animals, an essential complement to what she was discovering on the beaches.

And all this while she maintained her dedication to her plant collection, and her historical investigations. If this were not enough, she started a small publishing enterprise, Ediciones Shanamaiim, through which she published her famous book 'Tierra del Fuego', a kind of naturalist and tourist guide which even now remains current, as well as a map of Tierra del Fuego. Both were exquisitely illustrated with her naive-style drawings that precisely represented their subjects.

In just a few years, Natalie became a world authority on cetaceans, especially small cetaceans. Her osteological collection and the samples she collected were and still are accessed by colleagues around the world. Her collection of Commerson's dolphins, Cephorhynchus commersoni; Peale's dolphins, Lagenorhynchus australis; hourglass dolphins, $L$. cruciger; and spectacled porpoises are and will remain the most important in the world for decades. The collection houses two skeletons of the little-known Hector's beaked whale, Mesoplodon hectori. If this were not enough, she then became interested in collecting bird skeletons and added this taxon to her important collection.

Her work resulted in a collection of over 2850 mammal and 2500 bird skeletons, more than 200 scientific papers, book chapters, abstracts at scientific conferences and over 60 talks at scientific conferences. Natalie served on the IUCN/ SSC Cetacea Specialist Group for many years. In 1984, she was invited to be an international member of the Society of Woman Geographers. In 1995, Natalie was made a member of the US-based Explorers Club of New York. In 1996, she was awarded a Gold Medal from the Society of Woman Geographers for her study on the flora and fauna of Tierra del Fuego and made a member of the Ohio Women's Hall of Fame. Natalie received an honorary Doctorate of Science from Kent State University in 1997. All of this did not make her neglect her work at the Harberton Ranch, where she played a decisive role in the development of tourism at the ranch, which is now a major center for tourism in Tierra del Fuego. Although she worked at the Centro Austral de Investigaciones Científicas de Usuhaia for several years, for most of her career her scientific work in Tierra del Fuego was done ad honorem.

By the end of the 1990s, she had received support from Total Austral S.A., Propak Systems S.A., and Fondation D’Enterprise Total (France) to build the Museo Acatushún, which now houses her collection at Harberton Ranch. The museum, which opened in 2001, includes an exhibition hall with several species of marine mammals and birds, and is visited by numerous tourists every year. The 'house of bones', located near the Museo, became the center for specimen preparation.

Over the years, she had numerous interns who learned the techniques of specimen preparation and cataloguing, as well as the biology of small cetaceans. Several of those interns are still working with her collection, some are pursuing doctoral degrees and others have become fully fledged researchers.

When looking back at only part of what Natalie did, it seems we are talking about the life of several people. It is difficult to describe Natalie's legacy, but she might be best summarized as the describer of the natural history of Tierra del Fuego. To live up to her example will remain a true challenge to those of us who survive her.

Natalie, we will miss your tenacity, your lemon pie, and combing the beaches with you after carefully calculating the tides. As I once said, you are now the tide. 